\title{
sciendo
}

10.2478/aucft-2019-0020

\section{PHYSICOCHEMICAL AND BIOCHEMICAL PROPERTIES OF GROUND PORK FORMULATED WITH ADDITION OF PRUNUS CERASUS (CV MONTMORENCY) EXTRACT AND SUBJECTED TO FREEZING STORAGE}

- Research paper -

\begin{abstract}
Ewelina Dorota POGORZELSKA-NOWICKA*, Marta BRODOWSKA**, Elżbieta GÓRSKAHORCZYCZAK**, Jolanta GODZISZEWSKA**, Anna SAKOWSKA*, Iwona WOJTASIKKALINOWSKA*, Agnieszka WIERZBICKA*
\end{abstract}

\author{
* Department of Technique and Food Product Development, Warsaw University of Life Sciences \\ (WULS-SGGW), NowoursynowskaStr 159 c, Warsaw, 02-776 Poland \\ ** Laboratory of Innovative Food Research, Warsaw University of Life Sciences (WULS-SGGW), \\ NowoursynowskaStr 159 c, Warsaw, 02-776 Poland
}

\begin{abstract}
Broad research interest is observed over last decade, toward searching for a new natural antioxidants, which could be applied in food industry. Especially attractive seems to be those rich in polyphenols, such as cherry. Thus,

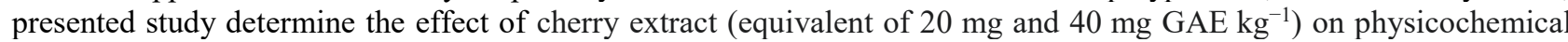
properties of ground pork frozen for 80 days. Samples were analyzed for color, color change, color attractiveness, myoglobin oxidation, fat oxidation, fatty acids profile, cooking loss, texture profile. The positive effect of cherry extract was observed for fat oxidation but cooking loss was higher in samples with extract addition. Color, color change, color attractiveness, myoglobin oxidation or fatty acids profile did not differ between groups.
\end{abstract}

Keywords: pork, cherry extract, polyphenols, freezing storage

\section{INTRODUCTION}

The most important characteristic of meat quality for consumers is visual appearance which consists of features such as marbling, fat content, color and drip loss. Among those attributes color is the most significant (Ngapo et al., 2010). Based on its' attractiveness consumers decide whether to buy meat. It has been proved that consumers directly correlate color with the freshness and with overall quality of meat (Banović et al., 2012). However, meat due to the chemical composition and physical structure is highly prone to oxidation. The oxidation processes may lead to color deterioration. Secondary products of lipid oxidation (malondialdehyde, n-alkanals, trans-2-alkenals and 4-hydroxy-trans-2-alkenals) combine covalent bonds with oxymyoglobin, changing its structure, what in turn makes it more susceptible to oxidation (Lee et al., 2003). Oxygenated myoglobin (oxymyoglobin) is responsible for pinky-red color of meat, highly acceptable by consumers.

Received: 12.11.2019.

Accepted in revised form: 9.12.2019
Oxymyoglobin after oxidation is transformed into metmyoglobin of brown color. Increased amount of this myoglobin form on meat surface changing its color from red to reddish brown ( $\mathrm{Hu}$ et al., 2019) what is for consumers an indicator of spoilage. Ground meat is particularly exposed to oxidation. Even freezing at very low temperatures $\left(-20^{\circ} \mathrm{C}\right)$ do not inhibit entirely the oxidation processes (Petrovic et al., 1993). Therefore, meat industry introduced, a bunch of antioxidants such as: propyl gallate (PG), nordihydroguaiaretic acid (NDGA), tertiary butylhydroquinone (TBHQ), trihydroxybutyrophenone (THBP), butylated hydroxytoluene (BHT) and butylated hydroxyanisole (BHA) in order to inhibit oxidative changes in meat. However, those are synthetic substances, what limits their application due to consumers' objections. According to previous studies consumers prefer natural ingredients over synthetic and increasingly seeking them on food labels (Hansen et al., 2010). Hence, the need for natural antioxidants in the meat industry arise. Nonetheless just a few from a huge amount of proposed natural antioxidants can be used as food ingredients, what is regulated by law. Before legal authorization of

\footnotetext{
${ }^{1}$ Corresponding author. E-Mail address: ewelina pogorzelska@sggw.pl
} 
new food additives, extensive research must be carried out. One of well-described, group of natural antioxidants are polyphenols. Their activity is so pronounced thanks to presence of many $-\mathrm{OH}$ groups and ortho-3, 4-dihydroxy structures. In many experiments the antioxidative potential of fruits rich in polyphenols: plums (Yildiz-Turp and Serdaroglu, 2010), grapes (Özvural and Vural, 2011), pomegranates (Devatkal et al. 2010) and apples (Huda et al., 2014) were tested. Most of those extracts $\backslash$ flourlpomace inhibited oxidative changes in meat. Additionally, our previous studies proved beneficial effect of cherry powder addition on lipid stability of pork (Brodowska et al., 2017). Thus, the authors hypothesized that the extract from cherries, fruits containing large amounts of flavonoids, might be useful as natural antioxidant with promising potential to use in meat industry. However, the addition of extracts can affect textural properties of meat (Yildiz-Turp and Serdaroglu, 2010), and to deteriorate its acceptability (Özvural and Vural, 2011). Therefore, the aim of presented study was to investigate the effect of Montmorency cherry powder extract addition on color, relative content of myoglobin forms, sensory acceptance of color as well as on fat oxidation and textural properties of ground pork meat stored under freezing conditions for 40 and 80 days.

\section{MATERIAL AND METHODS}

\section{Preparation of samples}

Research was conducted on a ground pork meat mixed with a jowl to a final fat content of $15 \%$. Both meat (Longossimusdorsim) and jowl was purchased in a local slaughterhouse and brought to laboratory in cold conditions $\left(4 \pm 1^{\circ} \mathrm{C}\right)$. Initially meat and jowl were aseptically cut into small pieces and then ground separately using a metal plates of $5 \mathrm{~mm}$ wholes' diameters (ZMM1089I grinder, Diana, Zellmer). After hand-mixing of ground meat with fat, $0.5 \%$ of salt was added. Then the prepared material was divided into three parts and each part was assigned to different treatment as follows: (i) Ccontrol with no additives, (ii) CEI- meat with addition of cherry extract to a content of $20 \mathrm{mg}$ GEA* $\mathrm{kg}^{-1}$ of meat (equivalent of gallic acid), (iii) CEII- meat with addition of cherry extract to a content of $40 \mathrm{mg} \mathrm{GEA} * \mathrm{~kg}^{-1}$ of meat. From each treatment group (of about $3.5 \mathrm{~kg}$ meat), three equalsize portions of meat were separate for analysis at day 0 (T0), and to freezing storage at about $-20 \pm 1^{\circ} \mathrm{C}$ for 40 and 80 days (T40 and T80 respectively).

\section{Analysis of pH values and basic composition}

Five $\mathrm{pH}$ measurements were made with the usage of a portable $\mathrm{pH}$ meter (Testo 205, Testo Ltd, Alton, Hampshire, UK), previously calibrated in buffers of $\mathrm{pH} 4.01$ and 7.00 at $20 \pm 1^{\circ} \mathrm{C}$. The data were collected by insertion glass electrode into meat for a depth of about $2 \mathrm{~cm}$, after reading stabilization. Obtained results were averaged and presented as mean $\pm \mathrm{SD}$. The $\mathrm{pH}$ measurements were made only at day 0 in order to eliminate meat with defects (DFD or PSE). However, we did not observed meat of poor quality (Table 1.). Formulated samples (control group) at day 0 were analyzed for water, fat, protein, ash and connective tissue content using
NIR Flex N-500 spectrometer of close infrared radiation (BÜCHI, Flawil, Switzerland) with spectral analysis software (NIR Ware 1.1, NIR Cal 5.1). Samples $(80 \mathrm{~g})$ were homogenized for analysis, placed into Petri dishes and scanned in triplicate. The readings for each component were averaged and presented as a percentage of the total composition (Table 1).

\begin{abstract}
Analysis of color
International Committee on Illumination (CIE) color values: L* (lightness; 100-white, 0-black), a* (redness), b* (yellowness) were measured on meat surface using Minolta CR-400 colorimeter (Konica Minolta Inc., Osaka, Japan). Device consisted of measuring head (CR-400) with measuring area diameter of $8 \mathrm{~mm}$ and $2^{\circ}$ standard observer. Before measurements colorimeter was calibrated using a white tile (D65: $Y=94.4, x=0.3172, y=0.3339$ ). Readings were taken at $20 \pm 1^{\circ} \mathrm{C}$ on 10 different locations on the sample surface, averaged and presented as least square means \pm SEM. Additionally Chroma $\left(\mathrm{C}^{*}\right)$ and Hue angle $\left(\mathrm{h}^{\circ}\right)$ was calculated based on $\mathrm{a}^{*}$ and $\mathrm{b}^{*}$ coordinates using the fallowing equations: $\mathrm{C}^{*}=\sqrt{ }\left[\left(\mathrm{a}^{*}\right)^{2}+\left(\mathrm{b}^{*}\right)^{2}\right]$ and $\mathrm{h}^{\circ}=\tan ^{-1}\left(\mathrm{~b}^{*} / \mathrm{a}^{*}\right)$.
\end{abstract}

As the indicator of meat discoloration in time $\Delta \mathrm{E}^{*}$ was calculated according to the equation:

$\Delta \mathrm{E}=\sqrt{\left(L 1^{*}-L 2^{*}\right)^{2}+\left(a 1^{*}-a 2 *\right)^{2}}+$ $+(b 1 *-\mathrm{b} 2 *)^{2}$

as well as $\Delta \mathrm{a}^{*}=\mathrm{a} 2{ }^{*}$-a $1^{*}$ and $\Delta \mathrm{h}^{\circ}=\mathrm{h} 2^{\circ}-\mathrm{h} 1^{\circ}$, where 1 are values at day $0 ; 2$ - values at days 40 and 80 .

\section{Analysis of oxymyoglobin, metmyoglobin and deoxymyoglobin relative content}

The formation of metmyoglobin (metMb), oxymyoglobin (oxyMb) and deoxymyoglobin (deoMb) on the meat surface was measured spectrophotometrically at the wavelengths $504 \mathrm{~nm}$ 
(for MetMb), $557 \mathrm{~nm}$ (DeoMb), $582 \mathrm{~nm}$ (OxyMb) and 525 (isobestic point). Percentage of each myoglobin form was calculated using the formulas presented by Tang et al. (2004) as follows:

$[$ DeoMb $]=-0.543 R_{1}+1.594 R_{2}+0.552 R_{3}-1.329$

$[\mathrm{OxyMb}]=0.722 \mathrm{R}_{1}-1.432 \mathrm{R}_{2}-1.659 \mathrm{R}_{3}+2.599$

$[\mathrm{MetMb}]=-0.159 \mathrm{R}_{1}-0.085 \mathrm{R}_{2}+1.262 \mathrm{R}_{3}-0.520$

where $\mathrm{R} 1=\mathrm{A} 582 / \mathrm{A} 525, \quad \mathrm{R} 2=\mathrm{A} 557 / \mathrm{A} 525$,

$\mathrm{R} 3=\mathrm{A} 504 / \mathrm{A} 525$. Sample preparation and myoglobin extraction was carried out according to AMSA Meat Colour Measurement Guidelines 2012 (Illinois, USA). Briefly one gram of meat was collected from the very surface of each sample in a $15 \mathrm{ml}$ test tube. After that $5 \mathrm{ml}$ of phosphate buffer $(\mathrm{pH} 8.0,0.01 \mathrm{M})$ was added and homogenized at $5000 \mathrm{rpm}$ using IKA T18 homogenizer for 40 seconds at $10 \pm 1^{\circ} \mathrm{C}$. Right after homogenization, slurry was directly located into an ice bath for 60 minutes and then centrifuged for $25 \mathrm{~min}$ at 10000 rpm (MPW 325R, MPW Med., Poland). The supernatant was filtered with Whatman No.1 filter and further clarified through a syringe filter with pore diameter of $0.4 \mu \mathrm{m}$.

\section{Sensory analysis}

Sensory evaluation of color attractiveness was conducted on a panel of eight, female, semi-trained researches, employed in Department of Technique and Food Development at Warsaw University of Life Sciences. Evaluation was conducted at day 0 and after 40 and 80 days of freezing storage. On each day of the storage, the same panelists made the assessment. The color ratings were made after cooking, on patties cooled to a room temperature. Before analysis samples were blinded by individually labeled random numbers and were served all at the same time. The panelist evaluated color of samples using a 8-point hedonic scale where 8 meant extremely desirable color and 1 meant extremely undesirable color.

\section{Analysis of fat oxidation degree (TBARS)}

TBARS value was measured in order to estimate the degree of fat oxidation using method as described by Brodowska et al. (2016), with some modifications. Briefly, each sample of about $2.5 \mathrm{~g}$ was homogenized at $1200 \mathrm{rpm}$ for $30 \mathrm{~s}$ (WT 500 homogenizer, Wiggenhauser, Germany) with 1.25 $\mathrm{ml}$ of antioxidant and $25 \mathrm{ml}$ of trichloroacetic acid (TCA). After homogenization, the obtained slurry was centrifuged ( $800 \mathrm{rpm}$ for about $10 \mathrm{~min}$ ) using MPW-251 centrifuge (MPW Med. Instruments, Warsaw, Poland). Then supernatant $(5 \mathrm{ml})$ was mixed with $0.02 \mathrm{M} 2$-thiobarbitutic acid solution (5 $\mathrm{ml}$ ) and incubated at $90^{\circ} \mathrm{C}$ for $40 \mathrm{~min}$. Right after incubation, samples were cooled down and absorbance was measured with the usage of UVVIS spectrophotometer (Shimadzu UV-1800, Tokyo, Japan) at $530 \mathrm{~nm}$. The results were expressed as mg of malondialdehyde (MDA) per kilogram of meat. Three repetitions were made for each sample.

\section{Fatty acids composition}

Fatty acid composition of tested samples was analyzed using method described by O'Fallon et al. (2007). The method is based on synthesis of methyl esters of fatty acids (FAME). Extracted fraction of methyl esters in hexane was then analyzed using Shimadzu GC-2010 gas chromatograph (Kyoto, Japan) equipped with capillary column $(100 \mathrm{~m} \mathrm{x}$ $0.25 \mathrm{~mm}$ ID and $0.2 \mu \mathrm{m}$ film thickness) $\mathrm{RT}^{\circledR}-22560$ (RESTEK, USA) and flame ionization detector (FID). Helium flow rate was $1.0 \mathrm{ml} / \mathrm{min}$. Injection volume was $1 \mathrm{~mL}$ with split ratio $70: 1$. Oven program: $140^{\circ} \mathrm{C}$ initial temperature for $5 \mathrm{~min}$, rate $4 \mathrm{C} / \mathrm{min}$ to $240^{\circ} \mathrm{C}$, hold time $30 \mathrm{~min}$. Injector temperatures were $240^{\circ} \mathrm{C}$ and detector temp. $260^{\circ} \mathrm{C}$. The individual fatty acids were detected comparing retention time to standard Supelco 37 FAME component. Each sample was analyzed in triplicate.

\section{Cooking loss}

Cooking loss [\%] of sample was presented as difference between weight of raw and cooked pattie, calculated according to formula:

$\%$ cooking loss $=$

raw pattie weight $(g)$ - cooked pattie weight $(g) \times 100$ raw pattie weight $(g)$

Freshly prepared patties were weighted, cooked and weighted again directly after cooking. Three patties were cooked for each treatment, measures were taken and then obtained results were averaged.

\section{Texture Profile Analysis (TPA)}

Prior to analysis freshly cooked patties were cooled to a temperature of $4 \pm 1^{\circ} \mathrm{C}$. Then, from each pattie was cut out cube with $10 \mathrm{~mm}$ side. Test was carried out using Instron 5965 Universal Testing Machine (Instron, Canton, Massachusetts,USA) equipped with $500 \mathrm{~N}$ load cell and flat cylindrical probe. Each sample was double-compressed with speed 250 $\mathrm{mm} \cdot \mathrm{min}^{-1}$ to a $50 \%$ of the original height, with a 3 second relaxation time between compressions. Parameters hardness [N], cohesiveness [-], gumminess $[\mathrm{N}]$, chewiness $[\mathrm{N} \cdot \mathrm{mm}]$ and springiness [mm] were calculated automatically from the forcetime plot by the Bluehill Software (2.0 version) combined with texture machine. The texture attribute of each sample was presented as an average of 6-7 measurements of cubes cut out from each pattie. 


\section{Statistical analysis}

All data were analyzed with the usage of STATISTICA v. 13.1 software (StatSoft, Tulsa, Oklahoma, USA). The experimental unit was single sample of ground meat. Most of the results were presented as Means with SEM (standard error of the mean). For analysis of the effect of time, treatment and timeand treatment interaction on color

\section{RESULTS AND DISCUSSION}

\section{pH level and basic composition of patties}

Results of basic composition and $\mathrm{pH}$ value of fresh pork patties measured right before freezing are presented in Table 1. The value of $\mathrm{pH}$ measures is typical $(\sim 5,7)$ for patties containing such amount of fat $(\sim 15 \%)$, what was described by Jeong et al. (2014). In case of basic composition, we noted slightly less protein and more water in comparison to mentioned studies. parameters, color change as well as on relative content of myoglobin forms a General Linear Model followed by Tukey HSD multiple range tests was applied. The data of sensory analysis of color attractiveness were analyzed using Mixed model consisting of time, treatment and treatment and time interactions as fixed effects and panelists as random effect.
Table 1. The basic chemical composition (\%) and $\mathrm{pH}$ values for control pork patties at day 0

\begin{tabular}{lccccc}
\hline & Moisture & Fat & Protein & Ash & $\mathrm{pH}$ \\
\hline Mean & 65.04 & 13.95 & 18.45 & 1.57 & 5.69 \\
SD & 0.06 & 0.07 & 0.16 & 0.21 & 0.01 \\
\hline
\end{tabular}

\section{Color evaluations}

An important factor affecting the color of meat was time $(\mathrm{P}<0.05)$. Storage period had influence on all color parameters, except for $\mathrm{a}^{*}$ component (Table 2).

Table 2. The effect of treatment and storage time on $\mathrm{L}^{*}, \mathrm{a}^{*}, \mathrm{~b}^{*}, \mathrm{C}^{*}$ and $\mathrm{h}^{\mathrm{o}}$ color parameters (least square means and SEM)

\begin{tabular}{|c|c|c|c|c|c|c|c|}
\hline \multirow[b]{2}{*}{ Treatment $^{1}$} & \multicolumn{4}{|c|}{ Storage (days) } & \multicolumn{3}{|c|}{ p-value } \\
\hline & 0 & 40 & 80 & SEM & Treatment & Time & $\begin{array}{c}\text { Treatment } \mathrm{x} \\
\text { Time }\end{array}$ \\
\hline $\mathrm{L}^{*}$ & & & & & 0.94 & $<0.001$ & 0.26 \\
\hline$C$ & $60.91^{\mathrm{a}}$ & $66.96^{\mathrm{b}}$ & $65.30^{\mathrm{b}}$ & 0.88 & & & \\
\hline$C E I$ & $62.79^{\mathrm{a}}$ & $66.15^{\mathrm{b}}$ & $64.90^{\mathrm{ab}}$ & 0.85 & & & \\
\hline CEII & 63.07 & 65.67 & 65.01 & 0.72 & & & \\
\hline SEM & 0.90 & 0.72 & 0.83 & & & & \\
\hline $\mathrm{a}^{*}$ & & & & & 0.53 & 0.07 & 0.37 \\
\hline$C$ & 11.19 & 11.43 & 10.18 & 0.31 & & & \\
\hline CEI & 11.36 & 11.12 & 10.40 & 0.46 & & & \\
\hline CEII & 10.47 & 10.73 & 10.70 & 0.36 & & & \\
\hline SEM & 0.36 & 0.38 & 0.41 & & & & \\
\hline $\mathrm{b}^{*}$ & & & & & 0.55 & $<0.001$ & 0.65 \\
\hline$C$ & $8.44^{\mathrm{a}}$ & $11.00^{\mathrm{b}}$ & $10.01^{\mathrm{c}}$ & 0.27 & & & \\
\hline$C E I$ & $9.19^{\mathrm{a}}$ & $11.01^{\mathrm{b}}$ & $9.83^{\mathrm{ab}}$ & 0.34 & & & \\
\hline CEII & 8.72 & 10.65 & 9.79 & 0.38 & & & \\
\hline SEM & 0.31 & 0.35 & 0.33 & & & & \\
\hline $\mathrm{C}^{*}$ & & & & & 0.51 & $<0.01$ & 0.68 \\
\hline$C$ & $14.02^{\mathrm{a}}$ & $15.87^{\mathrm{b}}$ & $14.30^{\mathrm{a}}$ & 0.35 & & & \\
\hline CEI & 14.62 & 15.65 & 14.32 & 0.55 & & & \\
\hline CEII & 13.64 & 15.13 & 14.51 & 0.50 & & & \\
\hline SEM & 0.45 & 0.48 & 0.49 & & & & \\
\hline $\mathrm{h}^{\mathrm{o}}$ & & & & & 0.56 & $<0.001$ & $<0.05$ \\
\hline$C$ & $36.97^{\mathrm{a}}$ & $43.90^{\mathrm{b}}$ & $44.65^{b}$ & 0.84 & & & \\
\hline$C E I$ & $38.99^{\mathrm{a}}$ & $44.85^{b}$ & $43.54^{\mathrm{b}}$ & 0.66 & & & \\
\hline CEII & $39.81^{\mathrm{a}}$ & $44.69^{b}$ & $42.35^{c}$ & 0.65 & & & \\
\hline SEM & 0.66 & 0.67 & 0.82 & & & & \\
\hline
\end{tabular}

${ }^{\mathrm{a}, \mathrm{b}}$ Different letters within the same row differ significantly $(P<0.05)$

A.B Different letters within the same column differ significantly $(P<0.05)$

${ }^{1}$ Treatments: C- control with no additives; CEI- meat with addition of cherry extract to a content of $20 \mathrm{mg} \mathrm{GEA}^{*} \mathrm{~kg}^{-1} \mathrm{of}^{-}$ meat (equivalent of gallic acid); CEII- meat with addition of cherry extract to a content of $40 \mathrm{mg} \mathrm{GEA*} \mathrm{kg}^{-1} \mathrm{of} \mathrm{meat.}$ 
The influence of applied supplementation was not reported, while interaction of time and supplementation was tested. In that case values foronly hue angle $\left(\mathrm{h}^{\circ}\right)$ differ. The lightness $\left(\mathrm{L}^{*}\right.$ value) increased over time in all tested groups. At the same time there were observed no changes in $a^{*}$ color parameters and increased values for $b^{*}$ components after 80 days of storage for control and CEI groups.

The increase in color lightness and the increase in the $\mathrm{b} *$ value during cold storage was noted in previous studies (Xia et al., 2009). The increased lipid oxidation processes (intensified with the time passage) are connected with yellow pigment formation in meat as a result of non-enzymatic browning reaction between amines from proteins or phospholipid head groups. Additionally, lightness increasing, is also reported after damages to the ultrastructure of muscle cells during freezing and thawing processes. Studies showed that increased extra-cellular water leakage after structural damage of cells, results in lighter color as a consequence of light reflectance and scatter (Xiong, 2000). Yet, in the case of $a^{*}$ parameter we observed opposite trend to those presented in previous studies. A vast majority of researches reports that redness of meat was decreased over time (Jeong et al., 2006; Kim et al., 2013). The differences seemed to relate to temperature and more specifically with exposures of larger area of meat to low temperature (ground meat). There is general agreement in the literature that at lower temperatures the red color is more stable because the oxidation processes of myoglobin decreases (Aidani et al., 2014). Regarding Chroma $\left(\mathrm{C}^{*}\right)$ it did not change along with storage time in any group, while $\mathrm{h}^{\circ}$ increased in all groups. According to those results vividness of color of tested samples did not change, while the values of $h^{\circ}$ parameters at the end of storage suggest that color of all samples blurred in the direction of the yellow shade. Since hue angle is consider as a determinant of color change detectable by human eye, we assumed that color got worse in time (Ripoll et al., 2008). Presented studies are partially in line with results obtained by Terns et al. (2011), who found effect of day as significant regarding CIE $L^{*}$, $a^{*}$ and $b^{*}$ components. Similarly, they did not noticed effect of interaction between supplementation and day of storage on color parameters, but in contrast to our findings they reported an influence of supplementation on $\mathrm{a}^{*}$ and $\mathrm{b}^{*}$ parameters. However, it is noteworthy that in mentioned study, researchers did not add pure cherry powder but the mix of cherry powder with bacterial starter cultures with nitrate reductase activity.

\section{Color change analysis}

The color change of tested samples over time was described using $\Delta \mathrm{E}, \Delta \mathrm{a}^{*}$ and $\Delta \mathrm{h}^{\circ}$ parameters as presented in Table 3.

Table 3. Effect of the treatment on the color change $\left(\Delta \mathrm{E} . \Delta \mathrm{a}^{*}\right.$ and $\left.\Delta \mathrm{h}^{\circ}\right)$ of raw ground meat after cold storage at $-20 \pm 1^{\circ} \mathrm{C}$ for 80 day (expressed as means).

\begin{tabular}{cccc}
\hline Treatment $^{1}$ & $\Delta \mathrm{E}$ & $\Delta \mathrm{a}$ & $\Delta \mathrm{h}^{\mathrm{o}}$ \\
\hline$C$ & 5.77 & -1.01 & $7.68^{\mathrm{A}}$ \\
$C E I$ & 4.18 & -0.96 & $4.55^{\mathrm{AB}}$ \\
$C E I I$ & 3.86 & 0.23 & $2.54^{\mathrm{B}}$ \\
SEM & 0.69 & 0.58 & 1.07
\end{tabular}

A.B Different letters within the same column differ significantly $(P<0.05)$

Values of total color differences $(\Delta \mathrm{E})$ indicated that color change was more than noticeable (appreciable) for all treatment groups according to the unites of National Bureau of Standards (NBS) (degree of perception by human eye: 0-0.5 trace, 0.5-1.5 slight, 1.5-3.0 noticeable, 3.0-6.0 appreciable, $6.0-12.0$ much, $>12.0$ very much) (CIE, 1977). Negative $\Delta \mathrm{a}^{*}$ values detected for control and CEI groups suggested a negative change in redness for those samples. Moreover, obtained differences were greater than 0.6 , what means that those differences might be detectable by consumers. In turn, for CEII was noted slight positive $\Delta \mathrm{a}^{*}$ value, meaning increase in redness with time. However, the differences were probably not detectable by human eye. Regarding $\Delta \mathrm{h}^{\circ}$ the highest change was observed for control group $(\mathrm{P}<0.05)$, and the change was also potentially visible for consumers for CEI and CEII groups $\left(\Delta \mathrm{h}^{\circ}>0.9\right)$ ( $\mathrm{Zhu}$ and Brewer 1999).

\section{Myoglobin status analysis}

Changes in the content of oxymoglobin in the supplemented groups during the freeze storage are shown in Figures 1,2 and 3. At day $0 \mathrm{OxyMb}$ content was higher in groups with addition of cherry extract in comparison to control group (Figure 1). After 40 days of cold storage the highest content of this form of myoglobin was detected in meat with the highest content of extract (CEII). On the last day of storage, the trend reversed, and the highest share of oxygenated $\mathrm{Mb}$ was recorded in the control group.

In the case of metmyoglobin at day 0 , the highest content was noted for control and CEII groups (Figure 2). After the first storage period (after 40 days), both groups with extract addition had the highest percentage of MetMb. However, by the end of storage in all groups the level of all myoglobin forms was near to equal. 
Regarding deoxymyoglobin, there were no differences in the content between supplemented groups (Figure 3). It was found only difference in DeoMb levels among storage days. The content of metmyoglobin did not exceed 56\% in any day of storage.

It has been shown that meat with the content of MetMb over $60 \%$ is perceived by consumers as brown, what is directly linked to its spoilage. However some authors postulated that decrease content of OxyMb is more adequate determinant to estimate shelf-life of meat (Mancini et al., 2003). Thus the meat from control group was characterized by the best ratio of myoglobin forms, what means the addition of cherry extract did not exert positive effect on myoglobin oxidation of ground pork meat subjected to freezing storage for 80 days. According to literature, discoloration of meat is linked to oxidative processes as well as to enzymatic metmyoglobin reducing systems (MRS) (Møller et al., 2006). After slaughter MRS responsible for reduction of metmyoglobin back to oxymyoglobin are gradually depleted. Additionally, metmyoglobin reducing activity is rapidly decreased after freezing storage (extracellular enzymes leakage, protein oxidation) (Leygonie et al., 2012). Phenolic compounds have ability to reduce metmyoglobin to oxymyoglobin and scavenge reactive species causing OxyMb oxidation. Moreover, most of them is water-soluble what gives them possibility for direct interaction with myoglobin.

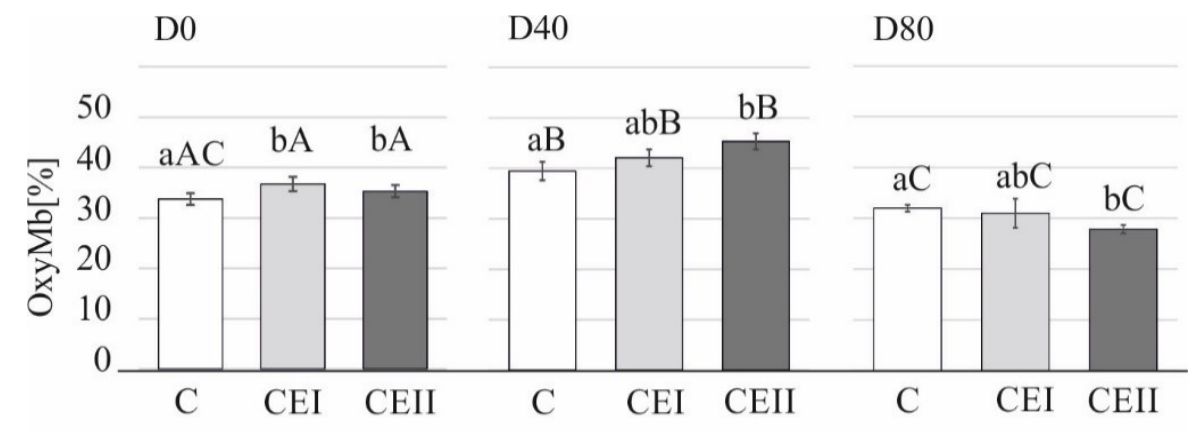

Figure 1. Oxymyoglobin content measured in ground pork meat formulated with different level of cherry powder extract, after 40 and 80 days of storage.

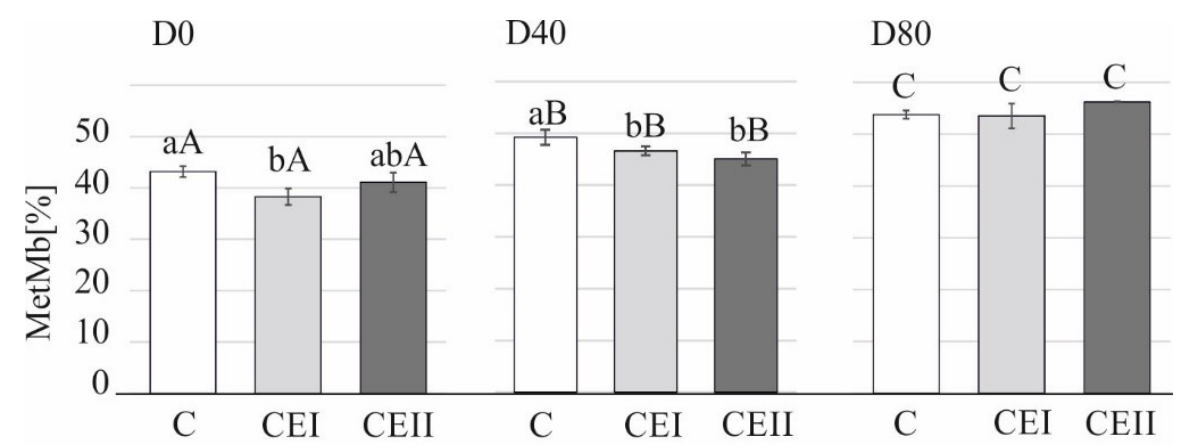

Figure 2. Metmyoglobin content measured in ground pork meat formulated with different level of cherry powder extract, after 40 and 80 days of storage.

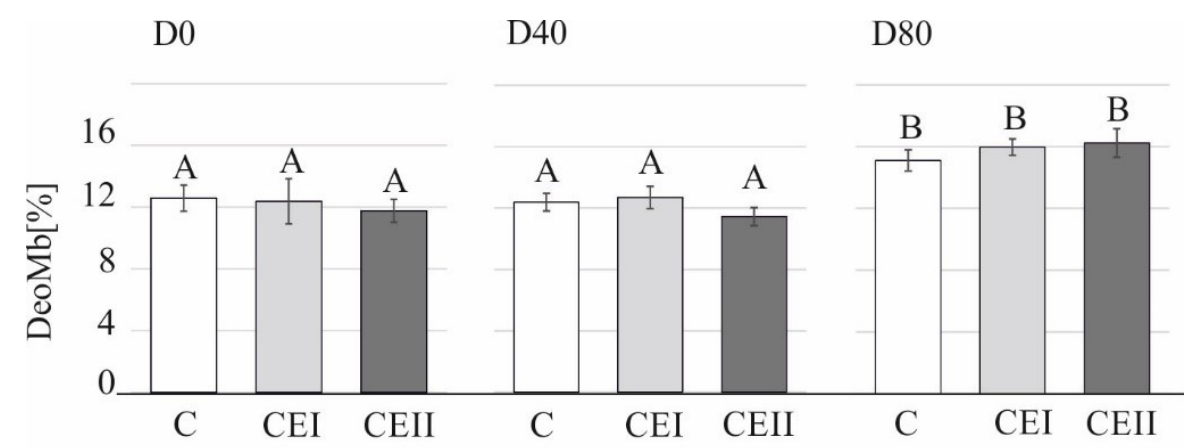

Figure 3. Deoksymyoglobin content measured in ground pork meat formulated with different level of cherry powder extract, after 40 and 80 days of storage. 
Studies on the effect of polyphenols and related plant origin phenolic compounds on the metmyoglobin reduction revealed that not all of those substances have same reduction power (Inai et al., 2014). Le (2012) who added mango waste (kernel or peel) rich in polyphenols documented positive effect on myoglobin oxidation. In turn Papuc et al. (2013) observed that the used dose of polyphenols has huge importance in case of oxidative properties. Dog rose fruits added in doses of 50,100 and $150 \mu \mathrm{g} \mathrm{GAE}^{*} \mathrm{~g}^{-1}$ of minced meat had antioxidant activity, while $200 \mu \mathrm{g} \mathrm{GAE}^{*} \mathrm{~g}^{-1}$ of minced meat act as prooxidant. In presented study we added small only 20 and $40 \mu \mathrm{g} / \mathrm{GAE}^{*} \mathrm{~g}^{-1}$ of minced meat what could be not sufficient to exert a positive antioxidant effects on myoglobin oxidation.

\section{Sensory analysis}

There were no differences observed in attractiveness of color ranked by consumers (Table 4) between tested groups. The attractiveness of color also did not change during the time of storage. In each group, each storage day the attractiveness of color was ranked by consumers around 5 (average) out of 8 possible points on hedonic scale. Thus, there were no adverse effect of cherry powder extract addition to pork patties on consumers acceptance of its color. Similar observation made Brodowska et al. (2017) in pork patties enriched with cherry extract and subjected to refrigerated storage for 8 days. Furthermore Salejda et al. (2018) also did not notice differences in consumers ratings of color acceptability between beef burgers with addition of cornelian cherry juice and burgers with no additives.

\section{Impact of cherry extract on TBARS values}

The effect of cherry powder extract addition on lipid oxidation measured in ground pork during freezing storage $\left(-20^{\circ} \mathrm{C}\right)$ are presented in Table 5 . There was observed significant impact of time, treatment as well as interaction between time and treatment on TBARS values. The lowest content of MDA per $\mathrm{kg}$ of meat was noted for control group. However, when comparing the total increase of fat oxidation in products between different supplementary groups for 80 days of storage, it appears that the slowest fat oxidation processes have been found in the meat with the greatest amount of additive. Equally slow, oxidized fat in the group with cherry extract addition in amount of $20 \mathrm{mg}$ gallic acid equivalent. Therefore, it can be concluded that the addition of Montmorency cherry extract slows down the fat oxidation in meat.

Table 4. Mean and SEM for sensory color scores obtained for meat with different levels of cherry powder extract.

\begin{tabular}{ccccccccc}
\hline & \multicolumn{3}{c}{ Storage (days) } & \multicolumn{5}{c}{$p$-value } \\
\hline Treatment $^{1}$ & 0 & 40 & 80 & SEM & Time & Treatment & $\begin{array}{c}\text { Treatment } \\
\text { x Time }\end{array}$ & $\Delta_{\text {TBARS }}{ }^{*}$ \\
\hline$C$ & $1.05^{\mathrm{Aa}}$ & $2.09^{\mathrm{Ab}}$ & $1.77^{\mathrm{Ac}}$ & 0.04 & & & & $0.72^{\mathrm{A}}$ \\
$C E I$ & $1.58^{\mathrm{Ba}}$ & $2.09^{\mathrm{Ab}}$ & $1.79^{\mathrm{Ac}}$ & 0.02 & $<0.001$ & $<0.001$ & $<0.001$ & $0.22^{\mathrm{B}}$ \\
$C E I I$ & $1.74^{\mathrm{Ca}}$ & $2.27^{\mathrm{Bb}}$ & $1.94^{\mathrm{Bc}}$ & 0.02 & & & & $0.20^{\mathrm{B}}$ \\
$S E M$ & 0.04 & 0.03 & 0.01 & & & & & 0.04 \\
\hline
\end{tabular}

${ }^{1}$ Treatments: C- control with no additives; CEI- meat with addition of cherry extract to a content of $20 \mathrm{mg} \mathrm{GEA}^{*} \mathrm{~kg}^{-1}$ of meat (equivalent of gallic acid); CEII- meat with addition of cherry extract to a content of $40 \mathrm{mg} \mathrm{GEA} * \mathrm{~kg}^{-1} \mathrm{of} \mathrm{meat.}^{\circ}$

Table 5. TBARS values depending on time and treatment expressed as $\mathrm{mg} \mathrm{MDA} / \mathrm{kg}$ of meat.

\begin{tabular}{|c|c|c|c|c|c|}
\hline Feature & Treatment $^{1}$ & & tim & & SEM \\
\hline & & 0 & 40 & 80 & \\
\hline$\frac{1}{2}$ & $C$ & 5.75 & 4.75 & 5.00 & 0.40 \\
\hline$\overline{0}$ & CEI & 5.75 & 4.88 & 5.38 & 0.44 \\
\hline 艼 & CEII & 5.63 & 5.25 & 5.75 & 0.46 \\
\hline & EM & 0.42 & 0.46 & 0.42 & \\
\hline
\end{tabular}

\footnotetext{
${ }^{a . b}$ Different letters within the same row differ significantly $(P<0.05)$

A.B Different letters within the same column differ significantly $(P<0.05)$

${ }^{1}$ Treatments: C- control with no additives; CEI- meat with addition of cherry extract to a content of $20 \mathrm{mg} \mathrm{GEA}^{*} \mathrm{~kg}^{-1} \mathrm{of}^{-}$ meat (equivalent of gallic acid); CEII- meat with addition of cherry extract to a content of $40 \mathrm{mg} \mathrm{GEA} * \mathrm{~kg}^{-1} \mathrm{of} \mathrm{meat}^{\circ}$

${ }^{*} \Delta_{\text {TBARS- }}$ Subtraction result of TBARS values at day 80 and day 0
} 
The obtained results correspond to those of Britt et al. (1998). In mentioned studies, cherry tissue of Balaton and Montmorency varieties were added to raw and fried beef patties at level of $11.5 \%$. As a result of cherry tissue addition, thiobarbituric acidreactive substances values drop and cholesterol oxidation decreased in raw and cooked meat. This indicates that the temperature during the processing and storage does not affect on the stability of used antioxidant, what is of high importance taking into consideration usage of the tested extract on an industrial scale. It has been proved that temperature variations may influence on some antioxidants mode of action (Réblová, 2012), changing them in some cases into pro-oxidants (Armando et al., 1998). Therefore, in the production of meat and meat products flavonoids have proven, better practical application than vitamin E (Kumar et al., 2013). Additional observation made during the storage was fluctuations of TBARS values between day 40 and 80 (increase and then decrease). Samples from all supplemented groups followed this pattern. The explanation for that might be the phenomenon described by Danowska-Oziewicz and Kurp (2017), who reported that during longer exposure to temperature or time, the secondary lipid oxidation products decomposes or reacts with some other food components, giving products which are not detectable by TBARS method.

\section{Fatty acids profile}

Addition of cherry powder extract did not inhibit decrease of polyunsaturated fatty acids (PUFA) in pork patties (Table 6). The reason could be too small dose of extract used for patties formulation and in consequence low content of polyphenols in samples. Papuc et al. (2013) noted that the antioxidative effect of polyphenol extracts is dependent on its concentration. However, there has been observed effect of time on PUFA content. The longer storage time was, the higher decrease of PUFA level was recorded. Contradictory, Brodowska et al. (2017) have not report effect of time on PUFA content in ground pork meat. The difference probably occurred from shorter storage time applied in mentioned study. With decrease of PUFA, we noted a slight increase of monounsaturated fatty acids (MUFA) and saturated fatty acids (SFA). What was possibly a result of lipid oxidation processes, which changed profile of fatty acids in tested samples (Wood et al., 2008). Both MUFA and SFA content increased over time. The effect of extract addition on the concentration of those fatty acids was also observed. Nonetheless combination of time of storage and treatment did not show any differences. In case of n6/n3 fatty acids ratio, pronounced significant difference was noted for control group after 40 days of freezing storage.

Table 6. Interactive effect of treatment x packaging time on fatty acids profile for pork patties subjected to freezing storage.

\begin{tabular}{|c|c|c|c|c|c|c|}
\hline & Storage (days) & Treatments & $\Sigma$ SFA & $\Sigma$ MUFA & $\Sigma$ PUFA & n6/n3 \\
\hline \multirow{3}{*}{\multicolumn{2}{|c|}{0}} & $\mathrm{C}$ & 40,54 & 47,45 & 11,54 & $9,09 \mathrm{a}$ \\
\hline & & CEI & 40,18 & 47,85 & 11,5 & $8,81 \mathrm{a}$ \\
\hline & & CEII & 40,09 & 47,85 & 11,61 & $8,74 \mathrm{a}$ \\
\hline \multirow{3}{*}{\multicolumn{2}{|c|}{40}} & $\mathrm{C}$ & 41,22 & 47,53 & 10,55 & $7,46 b$ \\
\hline & & CEI & 40,57 & 48,07 & 10,37 & $8,64 a$ \\
\hline & & CEII & 40,48 & 47,88 & 10,64 & $8,87 \mathrm{ab}$ \\
\hline \multirow{3}{*}{\multicolumn{2}{|c|}{80}} & $\mathrm{C}$ & 40,93 & 48,04 & 10,09 & $8,04 a$ \\
\hline & & CEI & 40,53 & 48,45 & 10,08 & $8,67 \mathrm{a}$ \\
\hline & & CEII & 40,14 & 48,76 & 10,13 & $8,95 \mathrm{a}$ \\
\hline S.E.M & & & 0,07 & 0,07 & 0,09 & 0,1 \\
\hline \multicolumn{7}{|c|}{ Significance of other effects (P-value) } \\
\hline Time & & & $* * *$ & $* * *$ & $* * *$ & $*$ \\
\hline Treatment & & & $* * *$ & $* * *$ & NS & $* * *$ \\
\hline
\end{tabular}

${ }^{1}$ Treatments: C- control with no additives; CEI- meat with addition of cherry extract to a content of $20 \mathrm{mg} \mathrm{GEA}^{*} \mathrm{~kg}^{-1}$ of meat (equivalent of gallic acid); CEII- meat with addition of cherry extract to a content of $40 \mathrm{mg} \mathrm{GEA} * \mathrm{~kg}^{-1}$ of meat ${ }^{\mathrm{a}, \mathrm{b}}$ Different letters within the same column differ significantly $(P<0.05)$

S.E.M - standard error of the mean $<$ NS- not significant; *** $\mathrm{P}<0,001 ; * \mathrm{P}<0,05$ 


\section{Cooking loss}

Changes in moisture content during frozen storage in patties formulated with different content of cherry powder extract is presented in Table 7 . There was significant effect of cherry powder extract addition on cooking loss of tested samples. Both treatment groups CEI and CEII (20 mg GEA* $\mathrm{kg}^{-1}$ meat and $40 \mathrm{mg} \mathrm{GEA}{ }^{*} \mathrm{~kg}^{-1}$ meat, respectively) had higher moisture loss in comparison to control group (with no additives). Moreover, the highest cooking loss was observed for the treatment group with highest content of cherry powder extract (CEII). It might be caused by acidity of added extract, which could decrease $\mathrm{pH}$ of tested samples and in consequence decrease water binding ability of proteins. Similarly, Salejda et al. (2018) noted greatest cooking loss of beef burgers formulated with the addition of cornelian cherry juice. Further, also Tyburcy et al. (2014) reported the same tendency in pork burgers formulated with cranberry and rose juices. Time of storage had no negative impact on cooking loss in all groups. The highest moisture drop was recorded for day 0 . After 40 and 80 day of freezing storage the moisture depletion was on the same level. Thus, the freezing storage did not affect on cooking loss of meat, what is in agreement with general statement of scientific literature that the cooking loss of meat is not affected by freezing storage (Leygonie et al., 2012; Vieira et al., 2009).

\section{Texture profile analysis}

Parameters of texture profile analysis of pork patties formulated with the addition of cherry powder extract and subjected to freezing storage are shown in Table 7. There were no significant differences in hardness of samples with different formulations. Thus, the addition of cherry extract did not reduce quality of pork patties. It is essential, because consumers prefer meat less hard, while it takes longer to consume harder meat (Akwetey and Knipe, 2012). The lack of differences in hardness between control group and treatment groups may occur because of not relevant differences in fat content and in polyunsaturated fatty acid ratio recorded in tested samples (Jones-Hamlow et al., 2015). Values of springiness and cohesiveness were slightly higher after freezing storage for control group (cohesiveness) and for control and CEI groups (springiness). The increase values of those parameters are linked to moisture loss. It has been reported that there is direct correlation between water content in meat and values of springiness and cohesiveness. The more water in meat, the lower values of springiness and cohesiveness are (Rongrong et al., 1998). In case of gumminess and chewiness, only in day 0 was noticed difference between control and treatment groups. Values of both parameters were lower for control patties in comparison to patties with cherry extract addition. After freezing storage, the difference disappeared. Obtained results are opposite to those of Salejda et al. (2018) who reported increase in hardness of burger batters formulated with the addition of cherry juice and to those of Tril et al (2011) who noted increase of hardness in pork patties with chokeberry juice additive. Nonetheless, similarly to Salejda et al. (2018) we observed impact of storage time in cold conditions on decrease of hardness values.

Table 7. Interactive effect of treatment x packaging time on attributes of texture profile analysis (TPA) and cooking loss (\%) for pork patties subjected to freezing storage.

\begin{tabular}{|c|c|c|c|c|c|c|c|}
\hline $\begin{array}{l}\text { Storage } \\
\text { (days) }\end{array}$ & Treatment & $\begin{array}{l}\text { Hardness } \\
(\mathrm{N})\end{array}$ & $\begin{array}{c}\text { Springness } \\
(\mathrm{mm})\end{array}$ & Cohesiveness & $\begin{array}{l}\text { Gumminess } \\
(\mathrm{N})\end{array}$ & $\begin{array}{c}\text { Chewiness } \\
(\mathrm{N} \cdot \mathrm{mm})\end{array}$ & $\begin{array}{c}\text { Cooking loss } \\
{[\%]}\end{array}$ \\
\hline \multirow[t]{3}{*}{0} & $\mathrm{C}$ & 19.45 & $0.29^{\mathrm{a}}$ & $0.24^{\mathrm{a}}$ & $4.57^{\mathrm{a}}$ & $1.37^{\mathrm{a}}$ & 30.19 \\
\hline & CEI & 18.97 & $0.4^{\mathrm{b}}$ & $0.31^{b c}$ & $5.74^{\mathrm{bc}}$ & $2.27^{\mathrm{bc}}$ & 31.86 \\
\hline & CEII & 19.57 & $0.36^{\mathrm{b}}$ & $0.29^{b}$ & $5.73^{\mathrm{bc}}$ & $2.12^{\mathrm{bc}}$ & 32.67 \\
\hline \multirow[t]{3}{*}{40} & $\mathrm{C}$ & 16.02 & $0.42^{\mathrm{b}}$ & $0.37^{\mathrm{e}}$ & $5.98^{\mathrm{c}}$ & $2.55 \mathrm{c}$ & 24.80 \\
\hline & CEI & 15.39 & $0.4^{\mathrm{b}}$ & $0.35^{\text {cde }}$ & $5.34^{\mathrm{abc}}$ & $2.15^{\mathrm{bc}}$ & 25.69 \\
\hline & CEII & 16.42 & $0.42^{\mathrm{b}}$ & $0.32^{\text {bcd }}$ & $5.27^{\mathrm{abc}}$ & $2.24^{\mathrm{bc}}$ & 26.18 \\
\hline \multirow[t]{3}{*}{80} & $\mathrm{C}$ & 14.16 & $0.38^{\mathrm{b}}$ & $0.32^{\text {cde }}$ & $4.58^{\mathrm{ab}}$ & $1.77^{\mathrm{ab}}$ & 24.82 \\
\hline & CEI & 13.49 & $0.41^{\mathrm{b}}$ & $0.35^{\text {de }}$ & $4.71^{\mathrm{ab}}$ & $1.95^{\mathrm{abc}}$ & 25.56 \\
\hline & CEII & 16.42 & $0.37^{b}$ & $0.31^{\text {bcd }}$ & $4.87^{\mathrm{abc}}$ & $1.82^{\mathrm{ab}}$ & 28.61 \\
\hline S.E.M & & 0.28 & 0.01 & 0.04 & 0.1 & 0.06 & 0.6 \\
\hline \multicolumn{8}{|c|}{ Significance of other effects (P-value) } \\
\hline Day & & $* * *$ & $* * *$ & $* * *$ & $* *$ & $* *$ & $* * *$ \\
\hline Treatments & & NS & * & $* *$ & NS & NS & $* * *$ \\
\hline
\end{tabular}

${ }^{1}$ Treatments: C- control with no additives; CEI- meat with addition of cherry extract to a content of $20 \mathrm{mg} \mathrm{GEA}^{*} \mathrm{~kg}^{-1}$ of meat (equivalent of gallic acid); CEII- meat with addition of cherry extract to a content of $40 \mathrm{mg} \mathrm{GEA} * \mathrm{~kg}^{-1}$ of meat; ${ }^{a, b}$ Different letters within the same column differ significantly $(P<0.05)$;

S.E.M - standard error of the mean; NS- not significant, *** $\mathrm{P}<0,001, * * \mathrm{P}<0,01 ; * \mathrm{P}<0,05$ 


\section{CONCLUSIONS}

Obtained results indicated that Prunus Cerasus (cv Montmorency) extract might be used in meat industry as natural antioxidant, in order to inhibit fat oxidation processes. Application of cherry extract in pork patties formulation did not change negatively color of meat, its attractiveness for consumers and texture profile, but increased slightly cooking loss. Thus, further studies are required to determine if higher doses of extract would impact positively on myoglobin oxidation and fatty acids profile, as equivalents of $20 \mathrm{mg}$ and $40 \mathrm{mg} \mathrm{GAE} \mathrm{kg}^{-1}$ were probably too small to inhibit adverse changes in meat.

\section{ACKNOWLEDGEMENTS}

Research financed by Polish Ministry of Science and Higher Education within funds of Department of Technique and Food Product Development, Warsaw University of Life Sciences (WULS-SGGW), for scientific research.

This work was supported by the Project BIOFOOD-innovative, functional products of animal origin no.POIG.01.01.02014-090/09 cofinanced by the European Union from the European Regional Development Fund within the Innovative Economy Operational Programme 2007-2013.

Conflict of interest

The authors declare no conflict of interest.

\section{REFERENCES}

1. Akwetey, W., \& Knipe, C. (2012). Sensory attributes and texture profile of beef burgers with gari. Meat Science, 92(4), 745-748. doi: 10.1016/j.meatsci.2012.06.032.

2. Armando, C., Maythe, S., \& Beatriz, N. P. (1998). Antioxidant activity of grapefruit seed extract on vegetable oils. Journal of the Science of Food and Agriculture, 77(4), 463-467. doi: 10.1002/(sici)10970010(199808)77:4<463::aid-jsfa62>3.0.co;2-1.

3. Banović, M., Fontes, M. A., Barreira, M. M., \& Grunert, K. G. (2012). Impact of Product Familiarity on Beef Quality Perception. Agribusiness, 28(2), 157-172. doi: 10.1002/agr.21290.

4. Britt, C., Gomaa, E. A., Gray, J. I., \&Booren, A. M. (1998). Influence of Cherry Tissue on Lipid Oxidation and Heterocyclic Aromatic Amine Formation in Ground Beef Patties. Journal of Agricultural and Food Chemistry, 46(12), 4891-4897. doi: 10.1021/jf980233y.

5. Brodowska, M., Guzek, D., Godziszewska, J., Górska-Horczyczak, E., Pogorzelska, E., Sakowska, A.,Wierzbicka, A. (2017). Cherry (Prunus cerasus cv Montmorency) extract with standardised antioxidant potential as preservative for refrigerated storage of ground pork. International Journal of Food Science \& Technology, 52(12), 2555-2563. doi: 10.1111/ijfs.13541.

6. CIE Recommendations on Uniform Color Spaces, Color-Difference Equations, and Metric Color Terms. (1977). Color Research \& Application, 2(1), 5-6. doi: 10.1002/j.1520-6378.1977.tb00102.x.

7. Danowska-Oziewicz, M., \& Kurp, L. (2017). Physicochemical properties, lipid oxidation and sensory attributes of pork patties with lupin protein concentrate stored in vacuum, modified atmosphere and frozen state. Meat Science, 131, 158-165. doi: 10.1016/j.meatsci.2017.05.009.

8. Devatkal, S. K., \& Naveena, B. (2010). Effect of salt, kinnow and pomegranate fruit by-product powders on color and oxidative stability of raw ground goat meat during refrigerated storage. Meat Science, 85(2), 306-311. doi: 10.1016/j.meatsci.2010.01.019.

9. Effect of chilling, freezing and thawing on meat quality: A review. (2014). International Journal of Biosciences (IJB), 5(4), 159-169. doi: 10.12692/ijb/5.4.159-169.

10. Hu, Y., Wang, Y., Tang, \& Y. (2019) Analysis of the correlation between the freshness indices of pork and its pork exudate. Acta Universitatis Cibiniensis. Series E: Food Technology, 23(1),63-69. doi: 10.2478/aucft-2019-0008

11. Hansen, T., Boye, H., \& Thomsen, T. U. (2010). Involvement, competencies, gender and food health information seeking. British Food Journal, 112(4), 387-402. doi: 10.1108/00070701011034402.

12. Huda, A.B., Parveen, S., Rather, S.A., Akhter, R., Hassan, M. (2014). Effect of incorporation of apple pomace on the physico-chemical, sensory and textural properties of mutton nuggets. International Journal of Advanced Research. 2(4): 974-983.

13. Inai, M., Miura, Y., Honda, S., Masuda, A., \& Masuda, T. (2014). Metmyoglobin Reduction by Polyphenols and Mechanism of the Conversion of Metmyoglobin to Oxymyoglobin by Quercetin. Journal of Agricultural and Food Chemistry, 62(4), 893-901. doi: 10.1021/jf404357h. 
14. Jeong, J. Y., Lim, S. T., \& Kim, C. J. (2016). The Quality Characteristics of Salted Ground Pork Patties Containing Various Fat Levels by Microwave Cooking. Korean Journal for Food Science of Animal Resources, 36(4), 538-546. doi: 10.5851/kosfa.2016.36.4.538.

15. Jeong, J.Y., Yang, H.S., Kang, G.H., Lee, J.I., Park, G.B., Joo, S.T. (2006). Effect of freeze-thaw process on myoglobin oxidation of pork loin during cold storage, Korean Journal for Food Science of Animal Resources, 26, 1-8.

16. Jones-Hamlow, K. A., Tavárez, M. A., Schroeder, A. L., \&Dilger, A. C. (2015). Lipid oxidation, sensory characteristics, and color of fresh pork sausage from immunologically castrated pigs stored frozen for up to 12 weeks. Food Science \& Nutrition, 4(3), 355-363. doi: 10.1002/fsn3.297.

17. Kim, G.-D., Jung, E.-Y., Lim, H.-J., Yang, H.-S., Joo, S.-T., \& Jeong, J.-Y. (2013). Influence of meat exudates on the quality characteristics of fresh and freeze-thawed pork. Meat Science, 95(2), 323-329. doi: 10.1016/j.meatsci.2013.05.007.

18. Kumar, P., Kumar, S., Ktripathi, M., Mehta, N., Ranjan, R., Bhat, Z., \& Singh, P. (2013). Flavonoids in the development of functional meat products: A review. Veterinary World, 6(8), 573. doi: 10.5455/vetworld.2013.573-578.

19. Le, M.H. (2012). Antioxidative effects of mango wastes on shelf life of pork products. Digital Ph.D thesis, Lincoln University, Christchurch, New Zealand.

20. Lee, S., Phillips, A., Liebler, D., \&Faustman, C. (2003). Porcine oxymyoglobin and lipid oxidation in vitro. Meat Science, 63(2), 241-247. doi: 10.1016/s0309-1740(02)00076-1.

21. Leygonie, C., Britz, T. J., \& Hoffman, L. C. (2012). Impact of freezing and thawing on the quality of meat: Review. Meat Science, 91(2), 93-98. doi: 10.1016/j.meatsci.2012.01.013.

22. Leygonie, C., Britz, T. J., \& Hoffman, L. C. (2012). Meat quality comparison between fresh and frozen/ thawed ostrich M. iliofibularis. Meat Science, 91(3), 364-368. doi: 10.1016/j.meatsci.2012.02.020.

23. Li, R., Carpenter, J. A., \& Cheney, R. (1998). Sensory and Instrumental Properties of Smoked Sausage Made with Mechanically Separated Poultry (MSP) Meat and Wheat Protein. Journal of Food Science, 63(5), 923-929. doi: 10.1111/j.1365-2621.1998.tb17928.x.

24. Mancini, R., Hunt, M., \& Kropf, D. (2003). Reflectance at 610 nanometers estimates oxymyoglobin content on the surface of ground beef. Meat Science, 64(2), 157-162. doi: 10.1016/s03091740(02)00174-2.

25. Møller, J. K. S., \&Skibsted, L. H. (2006). Myoglobins: the link between discoloration and lipid oxidation in muscle and meat. Química Nova, 29(6), 1270-1278. doi: 10.1590/s0100-40422006000600024.

26. Ngapo, T., Fortin, J., \& Martin, J.-F. (2010). Do pig farmers preferences bias consumer choice for pork? Response to critique of the pork preference studies. Meat Science, 85(4), 788-791. doi: 10.1016/j.meatsci.2010.03.022.

27. Özvural, E. B., \&Vural, H. (2011). Grape seed flour is a viable ingredient to improve the nutritional profile and reduce lipid oxidation of frankfurters. Meat Science, 88(1), 179-183. doi: 10.1016/j.meatsci.2010.12.022.

28. Papuc, C., Nicorescu, V., Predescu, N.C., Petcu, C. (2013). Antioxidant Activity of Polyphenols Extracted from Dog Rose (Rosa canina) Fruits on Myoglobin and Lipids in Refrigerated Minced Beef. Bulletin UASVM Veterinary Medicine, 70(1) from World Wide Web: http://agris.fao.org/agrissearch/search.do?recordID=RO2014100220.

29. Petrović, L., Grujić, R., \& Petrović, M. (1993). Definition of the optimal freezing rate-2. Investigation of the physico-chemical properties of beef M. longissimus dorsi frozen at different freezing rates. Meat Science, 33(3), 319-331. doi: 10.1016/0309-1740(93)90004-2.

30. Réblová, Z. (2012). Effect of temperature on the antioxidant activity of phenolic acids. Czech Journal of Food Sciences, 30(No. 2), 171-175. doi: 10.17221/57/2011-cjfs.

31. Ripoll, G., Joy, M., Muñoz, F., \&Albertí, P. (2008). Meat and fat colour as a tool to trace grass-feeding systems in light lamb production. Meat Science, 80(2), 239-248. doi: 10.1016/j.meatsci.2007.11.025.

32. Salejda, A. M., Kucharska, A. Z., \& Krasnowska, G. (2018). Effect of Cornelian Cherry (Cornus mas L.) Juice on Selected Quality Properties of Beef Burgers. Journal of Food Quality, 1-8. doi: $10.1155 / 2018 / 1563651$.

33. Tang, J., Faustman, C., Hoagland, T. A. (2006). Krzywicki Revisited: Equations for Spectrophotometric Determination of Myoglobin Redox Forms in Aqueous Meat Extracts. Journal of Food Science, 69(9), C717-C720. doi:10.1111/j.1365-2621.2004.tb09922.x. 
34. Terns, M. J., Milkowski, A. L., Rankin, S. A., \& Sindelar, J. J. (2011). Determining the impact of varying levels of cherry powder and starter culture on quality and sensory attributes of indirectly cured, emulsified cooked sausages. Meat Science, 88(2), 311-318. doi: 10.1016/j.meatsci.2011.01.009.

35. Tril, U., Salejda, A. M., \& Krasnowska, G. (2011). Attempt To Increase Oxidative Stability Of Model Meat Products By Applying Chokeberry Juice. Zywnosc. Nauka. Technologia. Jakosc/ Food.Science. Technology. Quality. doi: 10.15193/zntj/2011/79/055-066.

36. Tyburcy, A., Ścibisz, I., Rostek, E., Pasierbiewicz, A., \& Florowski, T. (2014). Antioxidative Properties Of Cranberry And Rose Juices In Meat Products Made Of DefrostedMeat. Zywnosc.Nauka.Technologia.Jakosc/Food.Science.Technology.Quality, （5(96). doi: 10.15193/zntj/2014/96/072-084.

37. Vieira, C., Diaz, M., Martínez, B., \& García-Cachán, M. (2009). Effect of frozen storage conditions (temperature and length of storage) on microbiological and sensory quality of rustic crossbred beef at different states of ageing. Meat Science, 83(3), 398-404. doi: 10.1016/j.meatsci.2009.06.013.

38. Wood, J., Enser, M., Fisher, A., Nute, G., Sheard, P., Richardson, R., ... Whittington, F. (2008). Fat deposition, fatty acid composition and meat quality: A review. Meat Science, 78(4), 343-358. doi: 10.1016/j.meatsci.2007.07.019.

39. Xia, X., Kong, B., Liu, Q., \& Liu, J. (2009). Physicochemical change and protein oxidation in porcine longissimus dorsi as influenced by different freeze-thaw cycles. Meat Science, 83(2), 239-245. doi: 10.1016/j.meatsci.2009.05.003.

40. Xiong, Y.L. (2000). Protein oxidation and implications for muscle food quality.In Edited by E. Decker \& C. Faustman, Antioxidants in muscle foods (pp. 3-23). Chichester. John Wiley \& Sons.

41. Y1ldiz-Turp, G., \&Serdaroglu, M. (2010). Effects of using plum puree on some properties of low fat beef patties. Meat Science, 86(4), 896-900. doi: 10.1016/j.meatsci.2010.07.009.

42. Zhu, L., \& Brewer, M. (1999). Relationship between instrumental and visual color in a raw, fresh beef and chicken model system. Journal of Muscle Foods, 10(2), 131-146. doi: 10.1111/j.17454573.1999.tb00391.x 